\title{
ANALISIS PERUBAHAN TROPICAL TROPOPAUSE LAYER DI BENUA MARITIM INDONESIA
}

\author{
Indah Susanti $^{1)}$, Sinta Berliana Sipayung \\ Pusat Sains dan Teknologi Atmosfer, LAPAN Jl. Djundjunan 133 Bandung 40173 \\ Email: ${ }^{1)}$ indahpl@ gmail.com
}

\begin{abstract}
Abstrak
Suhu merupakan parameter penting dalam perubahan iklim, dan perubahan suhu tersebut tidak hanya terjadi di permukaan bumi saja. Tropical Tropopause Layer (TTL), wilayah yang di dalamnya memiliki karakteristik troposfer dan stratosfer, merupakan bagian kritis dari atmosfer. Lapisan ini merupakan lapisan di daerah tropis antara level outflow konvektif utama dan titik dingin, sekitar 12-18 km. Penelitian ini bertujuan untuk mengidentikasi perubahan-perubahan yang terjadi di TTL yang difokuskan pada parameter suhu dan tekanan yang menjadi indikasi bagi perubahan pada parameter lainnya. Dengan menggunakan data Atmospheric Infrared Sounder (AIRS) versi 6 dengan resolusi vertikal $1 \mathrm{~km}$, resolusi horizontal 1 derajat, dan resolusi temporal bulanan (dari tahun 2003 sampai 2015), dianalisis perubahan TTL di atas Indonesia $\left(80-150^{\circ} \mathrm{BT}\right.$ dan $\left.20^{\circ} \mathrm{LS}-20^{\circ} \mathrm{LU}\right)$. Berdasarkan analisis deret waktu nampak bahwa suhu dan tekanan di TTL dalam periode yang dianalisis mengalami peningkatan. Hasil analisis menunjukkan bahwa karakteristik TTL, dipengaruhi oleh proses-proses konvektif dan proses radiative.
\end{abstract}

Kata-kata kunci: perubahan iklim, tropical tropopause layer, suhu, tekanan, konveksi, radiasi.

\begin{abstract}
Temperature is an important parameter in climate change, and the temperature changes not only occur on the surface of the earth only. Tropical Tropopause Layer (TTL), a region which has the characteristic troposphere and stratosphere, a critical part of the atmosphere, a layer in the tropics between the main convective outflow level and the cold point, about $12-18 \mathrm{~km}$. This study aims to identify changes occurring in the TTL that are focused on temperature and pressure parameters that are indicator for changes in other parameters. Using Atmospheric Infrared Sounder (AIRS) version 6 data with $1 \mathrm{~km}$ vertical resolution, 1-degree horizontal resolution, and monthly temporal resolution (from 2003 to 2015), analyzed TTL changes over Indonesia $\left(80-150^{\circ} \mathrm{BT}\right.$ and $\left.20^{\circ} \mathrm{LS}-20^{\circ} \mathrm{LU}\right)$. Based on the time series analysis, show increasing temperature and pressure in the TTL. The analysis results show that TTL characteristics, influenced by convective processes and radiative processes.
\end{abstract}

Keywords: climate change, tropical tropopause layer, temperature, pressure, convection, radiation.

\section{PENDAHULUAN}

Perubahan iklim sampai saat ini masih menjadi isu yang disoroti oleh banyak ilmuwan, terutama yang terkait dengan mekanisme dan faktor-faktor yang berkontribusi pada perubahan iklim. Suhu merupakan parameter penting dalam perubahan iklim, dan perubahan suhu tersebut tidak hanya terjadi di permukaan bumi saja. Prediksi berdasarkan General Circulation Model (GCM) menyatakan bahwa pada abad ke-21 terdapat peningkatan pemanasan maksimum di troposfer, di sekitar $200 \mathrm{hPa}$ (International Panel in Climate Change/IPCC, 2007) [1]. Kondisi ini memiliki implikasi penting 
terhadap sensitivitas iklim karena dampaknya pada umpan balik uap air, lapse rate, dan awan (Hartmann and Larson, 2002) [2], dan terhadap perubahan sirkulasi atmosfer (Butler et al, 2010) [3]. Beberapa studi, seperti yang dilakukan Santer (Santer, et al, 2008) [4], menunjukkan bukti-bukti bahwa perubahan suhu troposfer atas tropis lebih dari yang terjadi di permukaan pada skala waktu mukti-dekadal, meskipun beberapa analisis masih menduga sebaliknya, seperti yang dilakukan oleh Christy tahun 2007 [5].

Tropical Tropopause Layer (TTL), wilayah yang di dalamnya memiliki karakteristik troposfer dan stratosfer, merupakan bagian kritis dari atmosfer. Lapisan ini merupakan lapisan di daerah tropis antara level outflow konvektif utama dan titik dingin, sekitar 12-18 km (Highwood and Hoskins, ; 1998 [6]; Gettelman and Foster, 2002) [7]. TTL dipertahankan oleh adanya interaksi transport konvektif, gelombang yang dibangkitkan secara konvektif, radiasi, mikrofisika awan, dan sirkulasi stratosfer skala besar. TTL merupakan wilayah yang menjadi sumber udara lembab bagi stratosfer, sehingga sifat kimiawi kondisi batas stratosfer ditentukan di TTL. Awan-awan di TTL, baik awan sirus yang tipis dan convective anvils, memiliki dampak yang signifikan pada keseimbangan radiasi dan iklim di troposfer (Stephen, 2005) [8]. Selain itu, menurut Zhou dan Zhang (2011) [9], tropospause tropis dicirikan oleh adanya stabilitas statis dan skala waktu percampuran vertikal yang pendek yang kontras terhadap stratosfer. Hal tersebut menandakan transisi antara keseimbangan konvektif-radiatif dan keseimbangan radiatif.

Hal-hal yang terkait dengan perubahan suhu di troposfer atas dan di stratosfer bawah masih banyak yang belum diketahui secara pasti. Pemahaman terhadap suhu tropopaus bawah (dibawah 16 $\mathrm{km}$ ) dan suhu tropopaus atas (diatas $18 \mathrm{~km}$ ) di Benua Matitim Indonesia (BMI) menjadi sangat penting, yang secara umum suhu menurun sesuai dengan ketinggian. Secara khusus, tingkat terdingin suhu troposfer, yang dikenal dengan sebutan Cold Point Tropopause (CPT), berada di TTL. CPT ini diketahui memainkan peran penting dalam pertukaran stratosfer dan troposfer (Holton et al., 1995) [10] dan sangat menentukan konsentrasi uap air di stratosfer rendah (Mote et al., 1996) [11], yang berfungsi sebagai kunci konstituen radiasi untuk iklim permukaan (Forster et al, 2007 dan Solomon et al., 2010) [12 dan 13].

Perubahan pada TTL dapat terjadi sepanjang periode waktu sebagai respon terhadap forcing antropogenik sistem iklim. Kecenderungan ini merupakan tambahan terhadap variabilitas alami, yang melibatkan variasi inter-annual seperti Quasi Biennial Oscillation (QBO, 2 tahunan), ENSO (3-5 tahunan), siklus matahari (11 tahunan), atau transient variability yang terdorong oleh penyerapan dan pemencaran aerosol karena adanya erupsi vulkanik. Perubahan struktur termal TTL dapat mengubah awan-awan, mempengaruhi iklim global melalui umpan balik uap air dan awan (Bony et al., 2006) [14]. Sebaliknya, kondisi TTL dipengaruhi oleh banyak faktor seperti oleh adanya perubahanperubahan sirkulasi Hadley (Seidel et al., 2008) [15] dan sirkulasi Brewer-Dobson di stratosfer (Butchart et al., 2006) [16].

Beberapa studi telah dilakukan untuk meningkatkan pemahaman mengenai perubahan TTL, diantaranya adalah Seidel et al. (2008) yang menemukan adanya tren penurunan tekanan tropopaus (peningkatan ketinggian) berdasarkan rekaman radiosonda di daerah tropis. Selain itu, Gettelman dan Forster (2002) [17] telah mendeskripsikan klimatologi TTL, mencermati perubahan-perubahan berdasarkan data radiosonda, juga menemukan penurunan tekanan tropopaus (peningkatan ketinggian) dengan signifikansi perubahan yang kecil di dasar TTL.

Perkembangan teknologi satelit pada saat ini memungkinkan untuk memperoleh parameter yang terkait dengan perubahan kondisi tropopaus, terumana suhu, tekanan dan ketinggian dalam lingkup wilayah yang luas. Studi ini berfokus pada analisis perubahan suhu dan tekanan tropopaus dan identifikasi awal keterkaitannya dengan aktivitas konveksi yang diindikasikan dengan perubahan nilai OLR dengan menggunakan data Atmospheric Infrared Sounder (AIRS) dari satelit AQUA.

Komposisi dan iklim tropis di atmosfer atas dipengaruhi oleh TTL. Karakteristik kimia dan dinamikanya merupakan pertengahan antara troposfer dan stratosfer. Lapisan tropopaus dipertahankan oleh adanya interaksi komplek yang saling mempengaruhi antara pola-pola sirkulasi skala kecil dan besar, konveksi kuat, radiasi dan awan (Sherwood and Dessler, 2001) [18]. Udara troposfer masuk ke stratosfer terutama di daerah tropis. Konstituen yang terkait ozon dan aerosol dari stratosfer global, sebagaimana muatan uap air, ditentukan oleh komposisi udara di dekat tropopaus tropis. Selama beberapa tahun terakhir, telah muncul bahwa peningkatan yang lambat dan konveksi 
kuat yang cepat berkontribusi pada komposisi dan struktur termal lapisan tropopause tropis . Prosesproses pembentukan es pada suhu rendah mempengaruhi keberhasilan pengeringan beku saat udara melewati wilayah tropopaus yang dingin. Transport dan percampuran di wilayah tropopaus telah ditemukan berkaitan erat dengan monsoon Asia dan sistem sirkulasi tropis lainnya. Berdasarkan keterkaitan ini, perubahan iklim diperkirakan mempengaruhi lapisan tropopaus, contohnya seperti peningkatan upwelling udara skala besar dan potensi perubahan-perubahan konveksi tropis, suhu udara, komposisi kimia dan awan sirus. Penelitian ini lebih menekankan pada perubahan-perubahan yang terjadi di TTL yang difokuskan pada parameter suhu dan tekanan yang menjadi indikasi bagi perubahan pada parameter lainnya.

\section{METODE PENELITIAN}

Data yang digunakan adalah suhu dan tekanan tropopaus yang merupakan produk Atmospheric Infrared Sounder (AIRS) versi 6 yang dapat diunduh di ftp:/data/s4pa/Aqua_AIRS_Level3 /AIRX3STM/006. Format data yang diperoleh dalam bentuk hdf dengan resolusi vertikal $1 \mathrm{~km}$, resolusi horizontal 1 derajat, dan resolusi temporal bulanan dari September 2002 sampai Agustus 2016. Periode data yang digunakan dari Januari 2003 sampai Desember 2015 dengan cakupan wilayah $80-150^{\circ} \mathrm{BT}$ dan $20^{\circ} \mathrm{LS}-20^{\circ} \mathrm{LU}$

Metode yang digunakan adalah dengan menggunakan tren linier bulanan dan musiman, yang dibandingkan dengan parameter mixing rasio uap air, serta penggunaan hovmoller untuk mengetahui adanya perbedaan pola antara di utara dan selatan ekuator. Nilai yang digunakan untuk menganalisis kecenderungan berdasarkan waktu adalah nilai rata-rata dari seluruh grid pengamatan $80-150^{\circ} \mathrm{BT}$ dan $20^{\circ} \mathrm{LS}-20^{\circ} \mathrm{LU}$. Sedangkan yang digunakan untuk analisis hovmoller adalah dengan peratarataan longitudinal. Seluruh perhitungan dan visualisasi data menggunakan aplikasi Grads.

\section{HASIL DAN PEMBAHASAN}

Berdasarkan hasil pengolahan data AIRS bulanan yang telah dilakukan, dapat diketahui bahwa di tropopaus tropis Indonesia terjadi fluktuasi suhu dan tekanan dengan suhu dan tekanan maksimal (sekitar $195 \mathrm{~K}$ ) pada bulan Agustus saat belahan utara mengalami musim panas dan minimal (sekitar $189 \mathrm{~K}$ ) pada bulan Januari atau Februari saat belahan bumi utara mengalami musim dingin. Pola tahunan dari maksimal dan minimal ini sejalan dengan apa yang diungkapkan oleh Fueglistaler, et al. (2009) [19] yang menyatakan bahwa di sekitar tropopaus dan di stratosfer bawah, yaitu di sekitar 125 sampai $25 \mathrm{hPa}$, terdapat siklus tahunan yang jelas, dan untuk suhu lapisan di atasnya cendering dikontrol oleh osilasi stratosfer semitahunan yang menunjukkan lemahnya atau tidak adanya korelasi dengan suhu di level tropopaus. Di bawah level $125 \mathrm{hPa}$, variasi rata-rata tropis berkaitan dengan migrasi musiman Intertropical Convergence Zone (ITCZ) dan monsoon. Pola tahunan suhu troposfer tropis di Indonesia dan sekitarnya ini, juga terjadi untuk parameter tekanan tropopaus yang dapat diamati dari gambar 1 untuk periode data September 2002 sampai Agustus 2016.

Selain adanya fluktuasi suhu dan tekanan di troposfer, dari gambar 1 dapat juga diketahui bahwa terdapat kecenderungan peningkatan suhu dan tekanan di TTL Benua Maritim Indonesia. Dalam beberapa laporan disebutkan bahwa peningkatan suhu yang terjadi di TTL merupakan salah satu perubahan yang terjadi karena perubahan iklim global yang tidak hanya terjadi pada suhu di permukaan. Seperti yang dilaporkan oleh IPCC (2007), peningkatan suhu terbesar terjadi di ketinggian $200 \mathrm{hPa}$. 


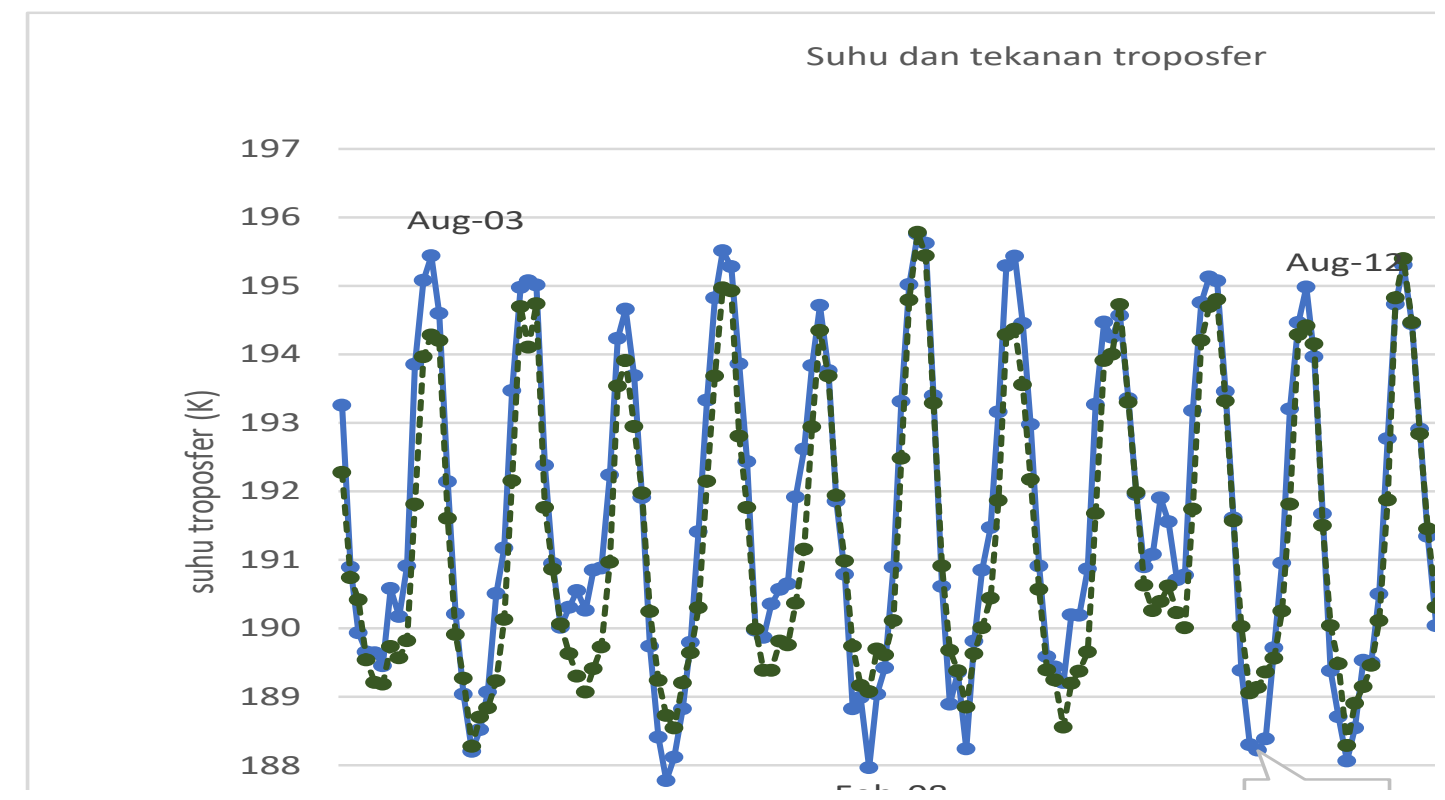

GAMBAR 1. Grafik suhu tropopaus rata-rata dari September 2002 - Agustus 2016 untuk wilayah dengan $80-150{ }^{\circ}$ BT dan $20^{\circ} \mathrm{LS}-20^{\circ} \mathrm{LU}$.

Secara latitudinal, terlihat adanya perbedaan antara tepat di ekuator, selatan dan utara ekuator, baik untuk parameter suhu maupun tekanan. Untuk daerah sekitar ekuator, variasi yang ditunjukkan lebih besar dibandingkan untuk di selatan dan utara ekuator. Dalam gambar 2 dapat dilihat bahwa nilai terendah dan tertinggi cenderung berada di sekitar ekuator. Beberapa periode menunjukkan nilai tinggi untuk di lintang yang lebih tinggi. Pada beberapa studi yang telah dilakukan, terdapat indikasi bahwa TTL dipengaruhi oleh QBO, ENSO di troposfer (Randel et al., 2013 dan Zhou et al., 2001) [20 dan 21], perubahan-perubahan sirkulasi Hadley (Seidel et al., 2008) [15] dan sirkulasi BrewerDobson di stratosfer (Butchart et al., 2006) [16]. Hal ini menunjukkan adanya kompleksitas faktorfaktor yang mempengaruhi TTL. Dalam gambar 2 dapat diketahui bahwa pada pertengahan tahun 2010 terjadi peningkatan suhu TTL di selatan dan utara ekuator. Demikian pula tahun 2015 dengan spasial yang lebih luas, peningkatan suhu terjadi di hampir semua lintang yang dikaji.

Untuk peningkatan suhu TTL pada tahun 2010 dapat dijelaskan dengan peristiwa ENSO. Pada tahun 2010 terjadi La Nina moderat (sumber: http://ggweather.com/), di saat terbentuk muatan uap air di atmosfer yang cukup banyak, dan hal ini dapat menjadi potensi sumber panas bagi atmosfer saat terjadi pelepasan panas ketika terjadi kondensasi. Namun, penjelasan ini tidak dapat digunakan untuk tahun 2015 yang justru terjadi El Nino sangat kuat (http://ggweather.com/). Namun demikian, terdapat kesamaan bahwa pada tahun 2010 dan 2015, uap air di atmosfer atas memang mengalami peningkatan. Berdasarkan Gambar 3 dapat diketahui bahwa pada tahun 2010 dan 2015 terjadi peningkatan mixing ratio uap air di ketinggian $100 \mathrm{hPa}$ mencapai lebih dari 0,0033 g/kg.

Fenomena El Nino kuat yang terjadi tahun 2015, di saat berbagai daerah mengalami kekeringan, pada kenyataannya di lapisan tropopaus tropis terhadap uap air dalam jumlah yang cukup besar. Pada Gambar 3 ditunjukkan bahwa pada tahun 2015, mixing ratio uap air di atmosfer atas mengalami peningkatan seperti yang terjadi pada periode 2010, namun pada periode 2015 tidak terbentuk curah hujan yang signifikan. Pola catatan yang sangat mencolok sedang terjadi pada tahun 2015 sampai awal 2016, yaitu suhu tinggi di Belahan Bumi Utara pada Februari 2016, suhu air laut di Indo Pasifik jauh lebih dingin dari biasanya, sementara ada uap air dan awan yang melanda seluruh samudra di dunia. Tapi, kecepatan anginnya lambat. Ini menunjukkan dari El Nino lebih besar daripada 1997-98. 
a.
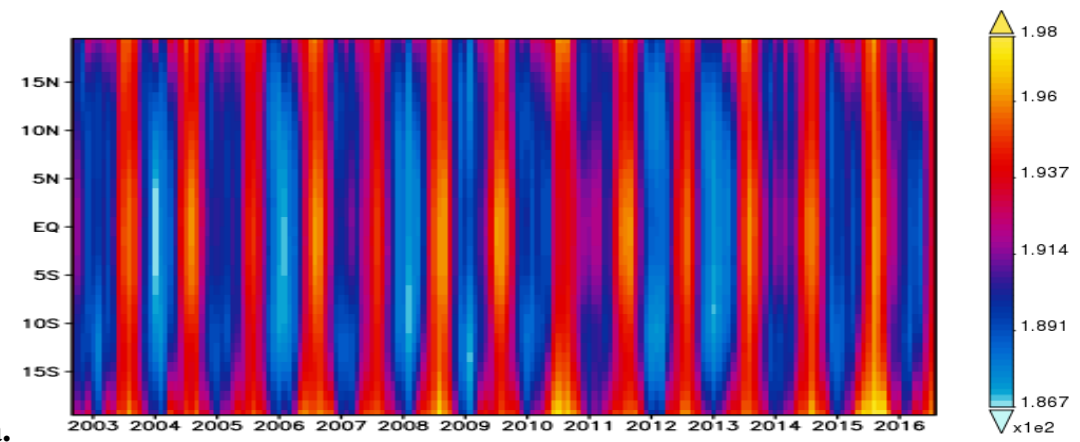

b.

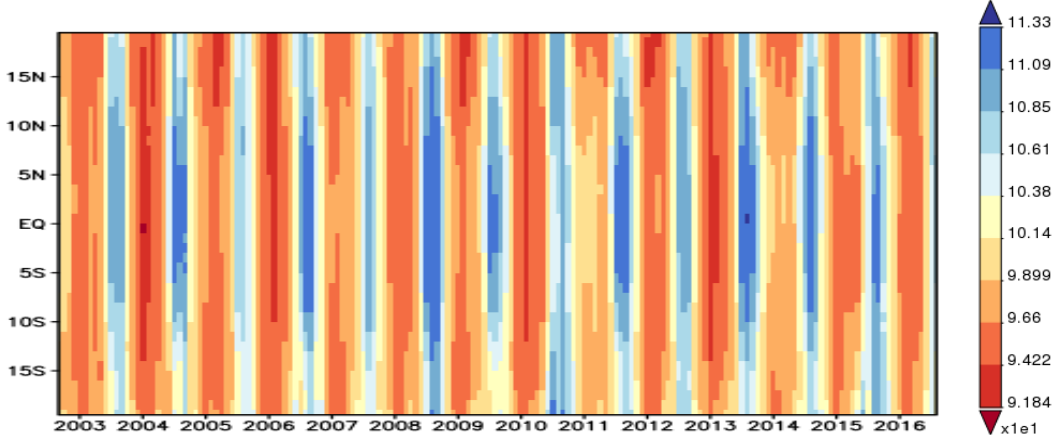

GAMBAR 2. Hovmoller suhu (a) dan tekanan (b) di tropopaus latitudinal dari September 2002 - Agustus 2016 untuk wilayah dengan $80-150^{\circ} \mathrm{BT}$ dan $20^{\circ} \mathrm{LS}-20^{\circ} \mathrm{LU}$.

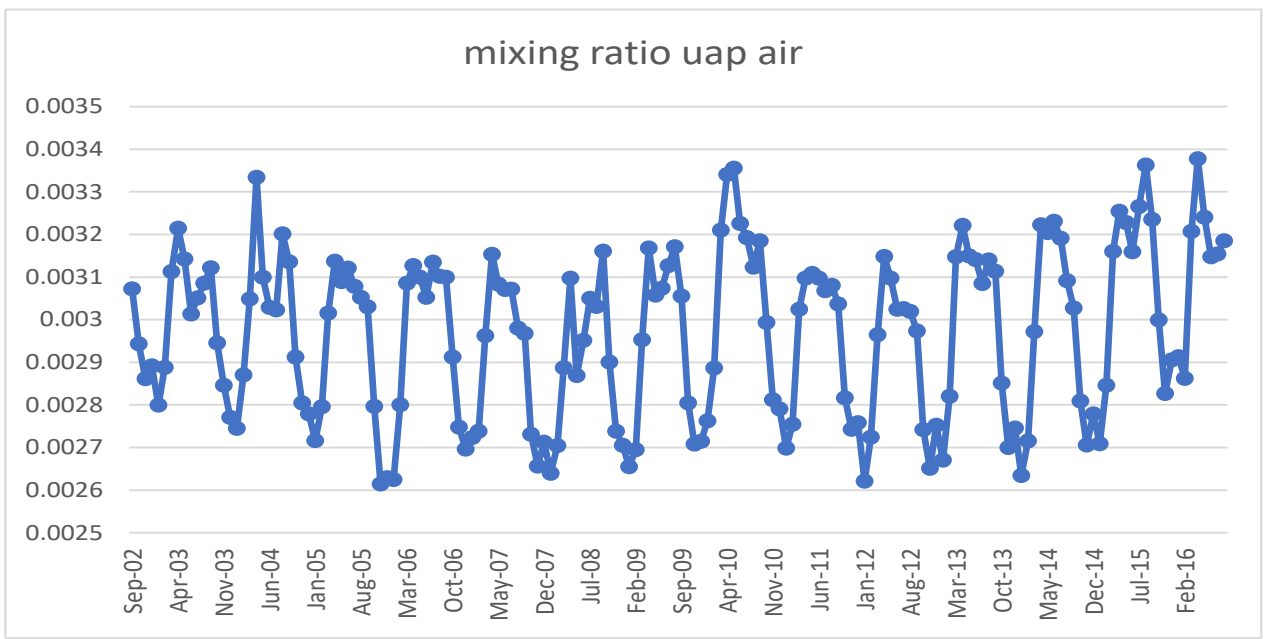

GAMBAR 3. Mixing ratio uap air dalam g/kg untuk periode September 2002 - Agustus 2016 di wilayah kajian ( 80 - 150 ${ }^{\circ} \mathrm{BT}$ dan $\left.20^{\circ} \mathrm{LS}-20^{\circ} \mathrm{LU}\right)$.

Selain ENSO, pengaruh monsun pada TTL juga terlihat jelas. Berdasarkan gambar 4 terlihat adanya perbedaan nilai yang sangat jelas antara periode DJF, MAM, JJA, dan SON, baik untuk parameter suhu, tekanan, maupun ketinggian atmosfer. Suhu dan tekanan pada periode JJA menunjukkan nilai yang paling tinggi, dan pada periode DJF menunjukkan nilai terendah. Sebaliknya, untuk parameter ketinggian tropopaus, pada periode DJF menunjukkan tropopaus yang lebih tinggi dibandingkan dengan pada periode JJA.

Suhu TTL menunjukkan perbedaan musiman, dengan nilai yang tendah pada saat musim dingin di utara, dan nilai yang lebih tinggi pada saat musim panas di utara ekuator. Dua mekanisme yang dapat digunakan untuk menjelaskan variasi musiman ini. Pertama adalah sirkulasi stratosfer, yang 
ditentukan oleh aliran ke atas di daerah tropis, dan aliran ke bawah di daerah ekstratropis, yang diketahui sebagai sirkulasi Brewer-Dobson, yang mengendalikan suhu melalui upwelling adiabatic (Holton et al., 1995) [22]. Kekuatan gelombang yang disebabkan oleh skala planet, skala sinoptik, dan disipasi gelombang gravitasi di stratosfer subtropis dan ekstratropis, terutama pada musim dingin, menggeser aliran di stratosfer ke arah kutub dan mempengaruhi gerakan ke atas di daerah tropis. Beberapa peneliti menyebutnya sebagai stratospheric pump (Plumb dan Eluszkiewicz, 1999) [23]. Peristiwa ini terjadi lebih kuat di belahan bumi utara, dan menginduksi gerakan ke atas dengan lebih kuat serta suhu yang lebih rendah pada musim dingin belahan bumi utara. Mekanisme kedua yang mempengaruhi suhu TTL adalah pengaruh sirkulasi meridional lokal di wilayah TTL yang disebabkan oleh gelombang ekuator (Kerr-Munslow and Norton, 2006) [24]. Gelombang ini muncul terutama oleh konveksi kuat yang bersifat lokal secara longitudinal di sekitar ekuator Pasifik barat. Karena konveksi lokal yang kuat terjadi di sekitar ekuator selama musim dingin di belahan bumi utara dan di sekitar $15^{\circ} \mathrm{LU}$ selama musim panas belahan bumi utara, daya gelombang ini lebih kuat di dekat TTL selama musim dingin belahan bumi utara. Dengan demikian, variasi suhu dan tekanan di TTL sangat dipengaruhi oleh proses konveksi dan radiasi yang mempengaruhi perbedaan suhu di belahan bumi utara dan belahan bumi selatan.

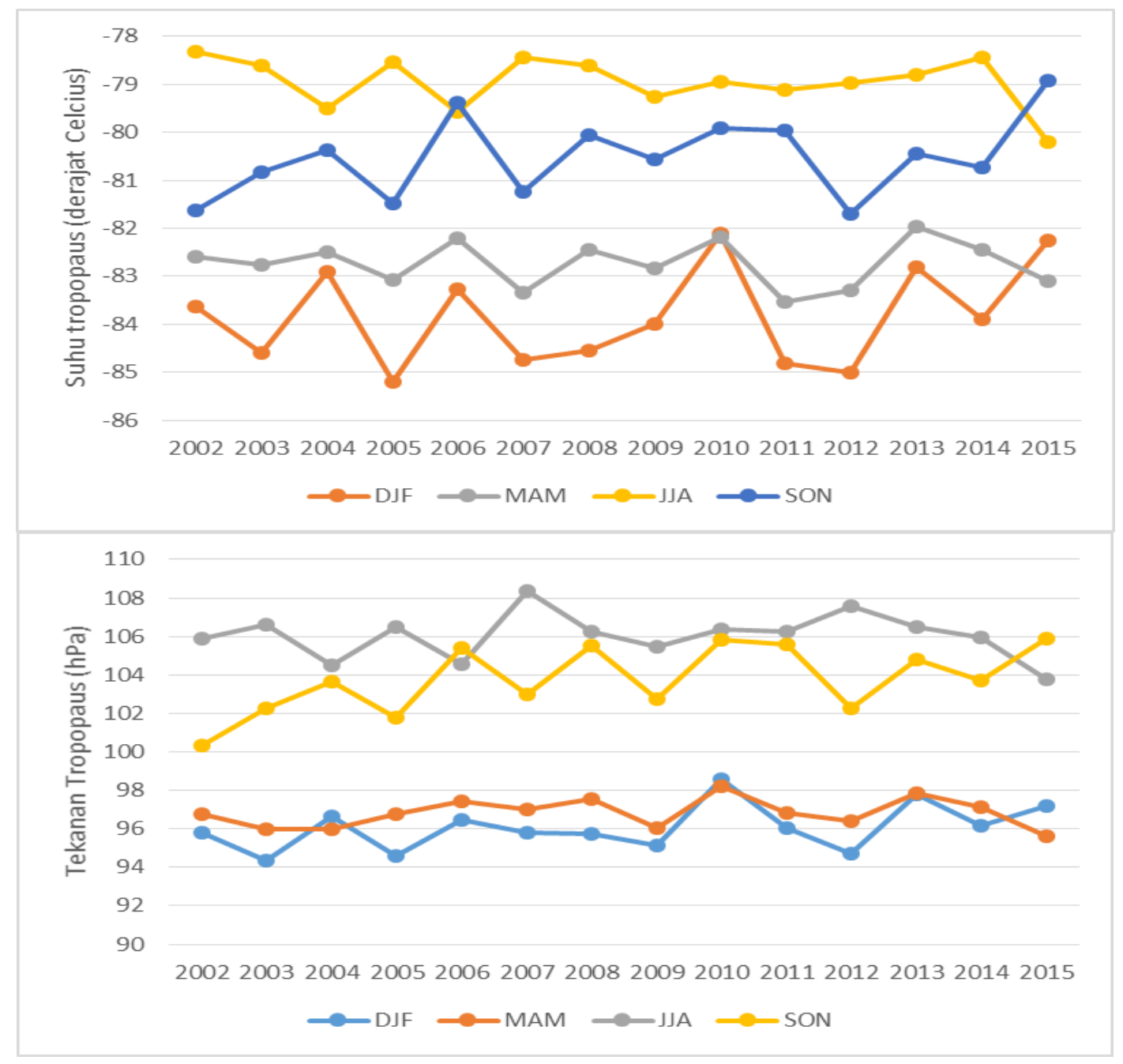

GAMBAR 4. Variasi musiman suhu dan tekanan tropopaus rata-rata untuk wilayah kajian 
Secara spasial, perbedaan suhu pada periode DJF dan JJA dapat dilihat pada gambar 5.
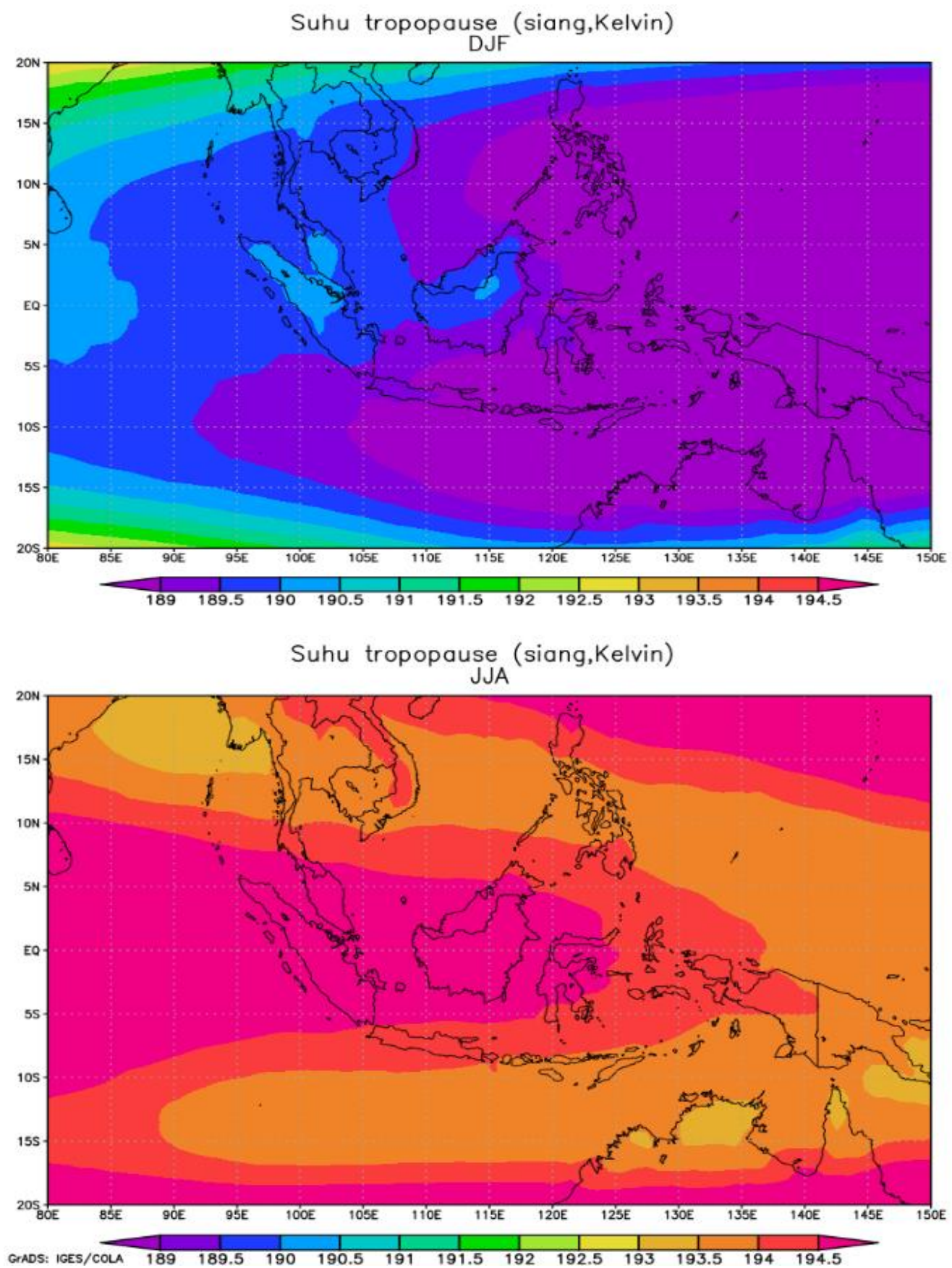

GAMBAR 5. Perbedaan spasial suhu tropopaus antara periode DJF dan JJA untuk wilayah kajian

\section{KESIMPULAN}

TTL sebagai wilayah kritis dan wilayah penghubung antara troposfer dan stratosfer, mengalami perubahan-perubahan. Kecenderungan umum yang terjadi, suhu dan tekanan tropopaus mengalami peningkatan dalam rentang periode yang dianalisis. Hal ini menunjukkan adanya pengaruh perubahan 
iklim. Selain itu, suhu TTL juga mengalami fluktuasi tahunan dan musiman sebagai hasil pengaruh QBO, ENSO, serta sirkulasi Brewer-Dobson.

\section{UCAPAN TERIMAKASIH}

Terima kasih kami ucapkan kepada semua rekan di Pusat Sains dan Teknologi Atmosfer yang telah membantu dan memberikan waktunya untuk berdiskusi sehingga makalah ini dapat diselesaikan.

\section{REFERENSI}

[1] IPCC, Climate Change, The Physical Basis, Contribution of Working Group I to the Fourth Assessment Report of the Intergovernmental Panel on Climate Change, Solomon, S., Qin, D., Manning, M., Chen, Z., Marquis, M., Averyt, K.B., Tignor, M., and Miller H.L. (Eds.), Cambridge Univ. Press, Cambridge, U.K. and New York, U.S.A., 2007. pp 996.

[2] Hartmann, D. L., and K. Larson, An important constraint on tropical cloud - climate feedback, Geophys. Res. Lett., 29(20), 1951, doi:10.1029/2002GL015835, 2002.

[3] Butler, A. H., D. W. J. Thompson, and R. Heikes, The steady-state atmospheric circulation response to climate change-like thermal forcings in a simple general circulation model, $\mathrm{J}$. Clim., 23, 3474-3496, doi:10.1175/2010JCLI3228.1, 2010.

[4] Santer, B. D., P. W. Thorne, L. Haimberger, K. E. Taylor, T.M.L. Wigley, J.R.Lanzante, S. Solomon, M. Free, P. J. Gleckler, P. D. Jones, T. R. Karl, S.A. Klein, C. Mears, D. Nychka, G.A. Schmidt, S.C. Sherwood, F.J. Wentz, Consistency of modelled and observed temperature trends in the tropical troposphere, International Journal of Climatology, Vol 28, Pages 1703 1722, Issue 13, 2008.

[5] Christy, J. R., W. B. Norris, R. W. Spencer, and J. J. Hnilo, Tropospheric temperature change since 1979 from tropical radiosonde and satellite measurements, J. Geophys. Res., 112, D06102, doi:10.1029/ 2005JD006881, 2007.

[6] Highwood, E. J., and B. J. Hoskins, The tropical tropopause, Q. J. R. Meteorol. Soc., 124(549), 1579-1604, doi:10.1002/qj.49712454911, 1998.

[7] Getterman, A., and PM.F. Forster, A Climatology of the Tropical Tropopause Layer, Journal of the Meteorological Society of Japan, Vol. 80, No. 4B, 2002, pp. 911-924.

[8] Stephens, G. L., Cloud Feedbacks in the Climate System: A Critical Review, J. Climate, 18, 237-273, 2005.

[9] Zhou, T., and J. Zhang, The vertical structures of atmospheric temperature anomalies associated with two flavors of El Niño simulated by AMIP II models, J. Clim., 24, 1053-1070, doi:10.1175/2010JCLI3504.1, 2011.

[10] Holton, J. R., P. H. Haynes, M. E. McIntyre, A. R. Douglass, R.B.Rood, and L. Pfister, Stratosphere-troposphere exchange, Rev. Geophys., 33, 403-439, 1995.

[11] Mote, P. W., and Coauthors, An atmospheric tape recorder: The imprint of tropical tropopause temperatures on stratospheric water vapor, J. Geophys. Res., 101, 3989-4006, 1996.

[12] Forster, P., V. Ramaswamy, P. Artaxo, T. Berntsen, R. Betts, D.W. Fahey, J. Haywood, J. Lean, D.C. Lowe, G. Myhre, J. Nganga, R. Prinn, G. Raga, M. Schulz and R. Van Dorland, Changes in Atmospheric Constituents and in Radiative Forcing, in: Climate Change 2007: The Physical Science Basis. Contribution of Working Group I to the Fourth Assessment Report of the Intergovernmental Panel on Climate Change. 2007.

[13] Solomon, S., D. Qin, M. Manning, Z. Chen, M. Marquis, K.B. Averyt, M. Tignor and H. L. Miller, Global climate projections in Climate Change 2007: The Physical Science Basis. Contribution of Working Group I to the Fourth Assessment Report of the Intergovernmental Panel on Climate Change, Cambridge University Press, Cambridge, United Kingdom and New York, NY, USA, 2010. 
[14] Bony, S., Colman, R., and Kattsov, V. M., How Well Do We Understand and Evaluate Climate Change Feedback Processes, J. Climate, 19, 3445-3482, 2006.

[15] Seidel, D.J., N. P. Gillett, J.R. Lanzante, K.P. Shine, and P.W. Thorne, Stratospheric Temperature trends: Our evolving Understanding, Wiley Interdiscip. Rev. Clim. Change, 2(4), 92-616, doi:10.1002/wcc.125, 2008.

[16] Butchart, N., A.A. Scaife, M. Bourqui, J. de Grandpré, S.H.E. Hare, J. Kettleborough, U. Langematz, E. Manzini, F. Sassi, K. Shibata, D. Shindell, and M. Sigmond, Simulations of anthropogenic change in the strength of the Brewer-Dobson circulation, Clim. Dyn., doi:10.1007/s00382-006-0162-4, 2006.

[17] Gettelman, A. and Forster, P. M. F.: A Climatology of the Tropical Tropopause Layer, J. Met. Soc. Jpn., 80, 911-924, 2002.

[18] Sherwood, S.C. and A.E. Dessler, A model for transport across the tropical tropopause, J. Atmos. Sci., 58, 765-779, 2001.

[19] Fueglistaler, S., A. E. Dessler, T. J. Dunkerton, I. Folkins, Q. Fu, and P. W. Mote, Tropical tropopause layer, Rev. Geophys., 47, RG1004, doi:10.1029/2008RG000267, 2009.

[20] Randel, W. J., and E. J. Jensen, Physical processes in the tropical tropopause layer and their roles in a changing climate, Nature Geoscience, 6, 169-176, doi:10.1038/ngeo1733, 2013.

[21] Zhou, X., M.A. Geller, and M. Zhang, Tropical cold point tropopause characteristics derived from ECMWF reanalyses and soundings, J. Climate, 14, 1823-1838, 2001.

[22] Holton, J. R., P. H. Haynes, M. E. McIntyre, A. R. Douglass, R. B. Rood, and L. Pfister, Stratosphere-troposphere exchange, Rev. Geophys., 33, 403-439, 1995.

[23] Plumb, R.A. and J. Eluszkiewicz, The Brewer-Dobson Circulation: Dynamics of the Tropical Upwelling, AMS Journal, doi.org/10.1175/1520-0469(1999)056, 1999.

[24] Kerr, AM., and W.A. Norton, Tropical Wave Driving of the Annual Cycle in Tropical Tropopause Temperatures, Journal of the Atmospheric Sciences, Vol. 63, 2006. 
